\title{
IMPACT OF THE COVID-19 PANDEMIC ON THE SMALL AND MEDIUM- SIZED BUSINESS ECONOMY IN RUSSIA AS AN EDUCATIONAL TOOL
}

\author{
Anastasia Alexandrovna Sarkisian-Artamonova ${ }^{1}$ \\ Olga Nikolaevna Kalacheva ${ }^{2 *}$ \\ ${ }^{1}$ SD, Plekhanov Russian University of Economics, Russian Federation, mosha98@yandex.ru \\ ${ }^{2}$ Associate Prof., Plekhanov Russian University of Economics, Russian Federation, \\ olgaklchv@rambler.ru \\ ${ }^{*}$ Corresponding Author
}

\begin{abstract}
As a result of the spread of the COVID-19 pandemic, restrictive measures have been introduced in Russia, as in other countries of the world, among them the suspension of the activities of a large number of enterprises, including small and medium-sized enterprises. According to available statistics, in Russia about $10 \%$ of graduates of higher education institutions in the field of accounting and economics run their own business or participate in family business. In this connection, priority should be given to disciplines that will provide knowledge and skills on the narrowly focused aspects of the activities of students of higher economic registration institutions, emphasizing the competencies of their chosen future profession. It is also important to identify those segments of small and medium-sized businesses that have been most affected by the quarantine. Research into the impact of the temporary suspension of the work of small and medium-sized business organizations, as the most sensitive segment of the economy, is impossible without a simultaneous analysis of measures to support small and medium-sized businesses by the State. One of the main challenges facing the Government is to increase the number of small and medium-sized businesses. This is because small enterprises, as an important part of the economic structure, increase the flexibility and adaptability of the economy, promote competition, create a special innovation environment and foster social stability, Promote the transition to a resource-efficient type of economic growth. Therefore, the comprehensive approach to education of accounting specialists in small and medium-sized enterprises, as described in our study, should be based on the disclosure of specific aspects, expressed concern about the possible prospects for the recovery of the economic sector in question.
\end{abstract}

Keywords: entrepreneurship, small and medium-sized business, entrepreneurship, COVID-19

\section{INTRODUCTION}

Since the beginning of 2020, the spread of COVID-19 infection has reached its peak in the spring of this year, so the epidemic has grown into a pandemic. The authorities of all States, including Russia, have begun to impose various forms of restrictions and quarantine, ranging from restricting people's freedom of movement and closing borders to temporarily suspending a large number of enterprises. Such restrictions 
have undoubtedly become a threat to business in the country, and especially to small and medium-sized businesses, for which every day of downtime means considerable losses. In this connection, these organizations, as well as the accounting professionals working in this field, have encountered many difficulties and problems requiring specific skills and competencies to be implemented in the field of education, for survival and business recovery.

The purpose of our research was to study the impact of the imposed State restrictions in Russia related to the spread of COVID-19 infection on the activities of small and medium-sized businesses, as well as the importance of education for specialists in the field of small and medium-sized business in modern crisis conditions. The objectives of the study were to analyses the situation of small and medium-sized enterprises in Russia in the context of the pandemic and to consider the impact of the restrictive measures imposed on their activities; Study of measures to support small and medium-sized enterprises by the State; Assessment of the impact of the education of specialists in the field of accounting for small and medium-sized businesses on contemporary conditions.

\section{LITERATURE REVIEW}

Small and medium-sized businesses are the backbone of the European economy. It accounts for $99.8 \%$ of all economic entities in Europe (Juergensen, 2020). In the Russian economy - about $20 \%$. The scale, specificity of activity and ownership structure determine the low need for substantial investments, so they are attractive for opening young specialists and graduates of educational institutions. Human capital is considered particularly important (Cowling, 2018). That in the context of a pandemic takes on a high degree of danger, as the virus is transmitted from person to person and people are not yet immune to the new virus (Jovanović, 2020). It is known that small and medium-sized enterprises are extremely important for the economy of any country (Liñán, 2020).

Many researchers have shown that small enterprises, by providing social stability, provide jobs, and generate public interest in economic stability and resource conservation. (Akhmadeev, 2019). Many researchers have confirmed the importance and necessity of government intervention and assistance to small businesses, which contributes to their unquestionable growth (Orzechowski, 2020).

Due to its small size, the business segment under consideration is able to react quickly to changes in the market, adjusting to its new conditions and requirements (Rozak, 2021). Small business represents the sphere of economy that represents the world community's most vivid inventions and innovations (Nummela, 2020; Morozova, 2020; Exposito-2020). On the other hand, however, this implies greater vulnerability to economic instability and crisis. (Avvakumova, 2020). It is also important to develop positive and professional thinking in the field of entrepreneurship among students of higher educational institutions. Unfortunately, there are countries like the United Arab Emirates where students have developed a negative entrepreneurial culture (Facchini, 2020)

\subsection{Theoretical Background}

COVID-19 is an external shock of unprecedented force that has affected the performance of small businesses in all countries. Since May 2020, $41 \%$ of British SMEs have ceased to operate and $35 \%$ feared that they would not be able to reopen and continue their operations. In Germany, 50 percent of small and medium-sized enterprises projected a significant decline in profitability due to the crisis, with one third expecting a drop of more than 10 percent. In Italy, more than $70 \%$ of small businesses were directly affected by the crisis (Juergensen, 2020)

As a result of the imposition of restrictive measures and the forced closure of a number of enterprises in the Russian Federation due to the spread of COVID-19 infection, as of 30 March 37\% of outlets throughout Russia were temporarily suspended. The most significant impact of the quarantine was on the shops of the small and medium-sized business segment of non-food goods and services: 85 percent of clothing and shoe shops were suspended, 78 percent of flower stands and shops, 71 percent of fitness centers, more than half of cafeterias were suspended, cafes and restaurants.

Small and medium-sized businesses are the most at risk in the current situation. During the initial stages of the introduction of restrictive measures according to Rosstat data in April - June 2020, the number of microenterprises in Russia showed no trend towards a decrease (Figure 1). 


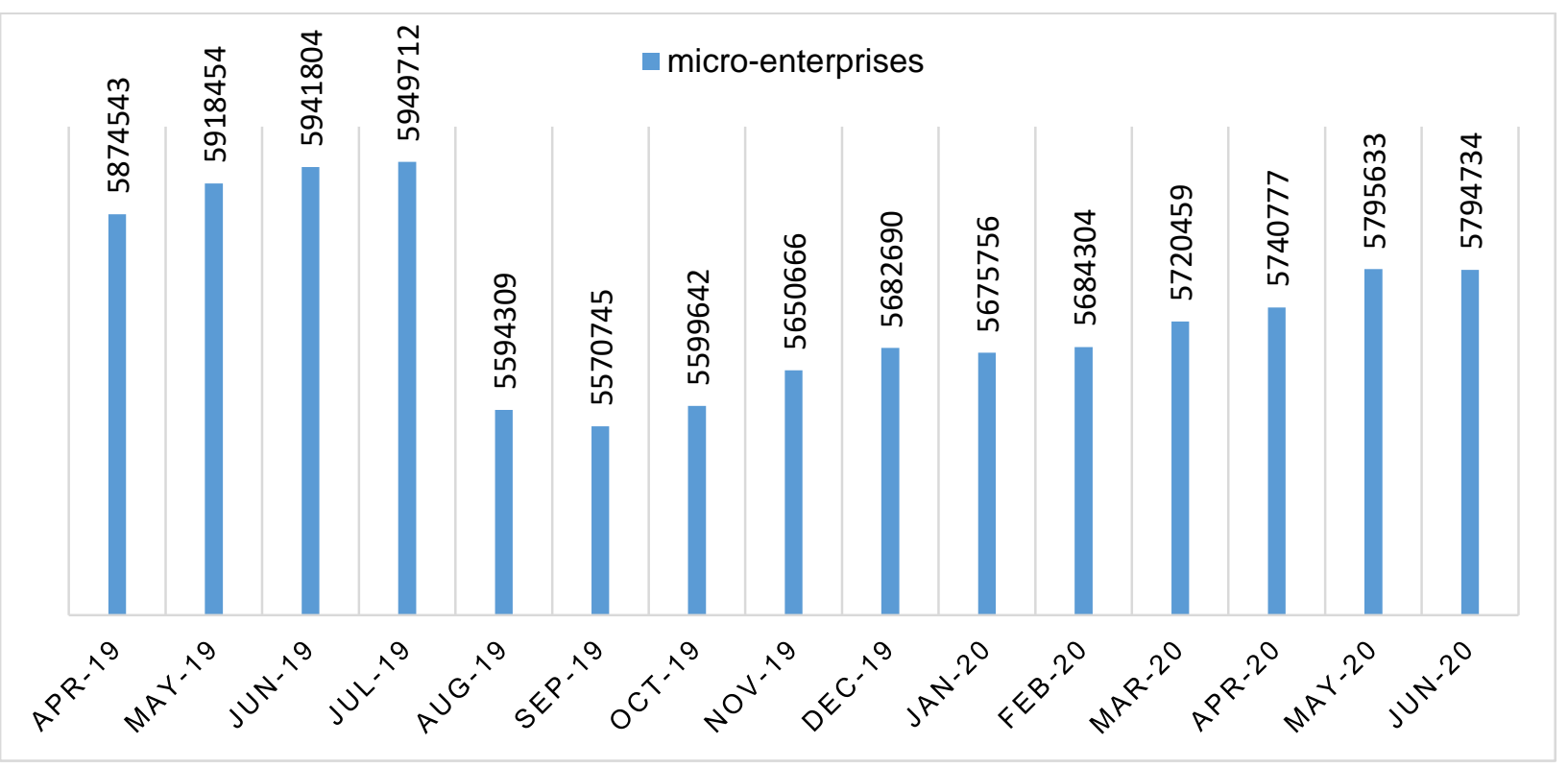

Fig 1. Number of micro-enterprises in Russia from April 2019 to June 2020 (compiled by the author on the basis of FSSS data) 1

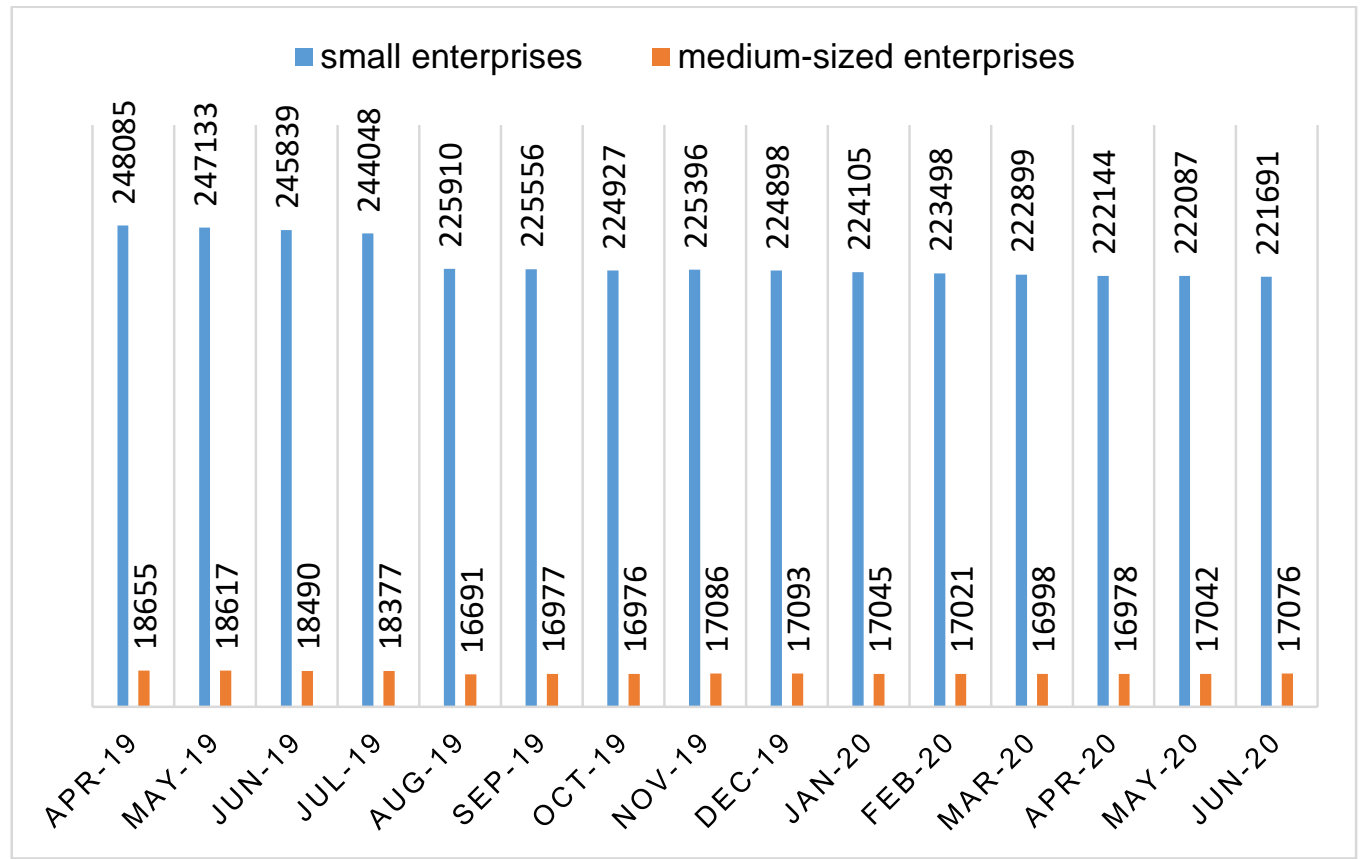

However, from the statistics on small and medium-sized companies, excluding micro-enterprises, it can be seen that by early April 2020 and in the following months, the number of small enterprises throughout the country began to decline significantly (Figure 2).

Fig. 2. Number of small and medium-sized enterprises in Russia from April 2019 to June 2020 (compiled by the author on the basis of FSSS data https://www.gks.ru)2

With the measures introduced to suspend most enterprises, it can be assumed that further statistics on the results of 2020 may show a decline in small and medium-sized enterprises whose economy is still in a «frozen state», but could collapse by the end of the year, because all the downtime of sales, production, service delivery could not but affect the economic condition of practically every small and medium business segment company.

\section{RESULTS AND DISCUSSION}

According To The Data Of IT-Company Analyst «Evotor», Which Is A Supplier Of Online Cash Registers For 
Small Enterprises, In April 2020 Turnover Of Russian Small And Medium-Sized Enterprises Decreased By 54\%, And In May - Business Lost $41 \%$ Of Proceeds. (EVOTOR, 2020). In Figure 3, Compiled On The Basis Of The Analysis Of Data Of More Than 650 Thousand Online-Cashiers Of «Evotor» In The Whole Territory Of Russia, It Is Evident That The Most Affected Segments Of Small And Medium-Sized Enterprises Became Trade In Non-Food Goods And Services. Already In March, There Was A Decline In Turnover In These Industries As The Pandemic Spread.

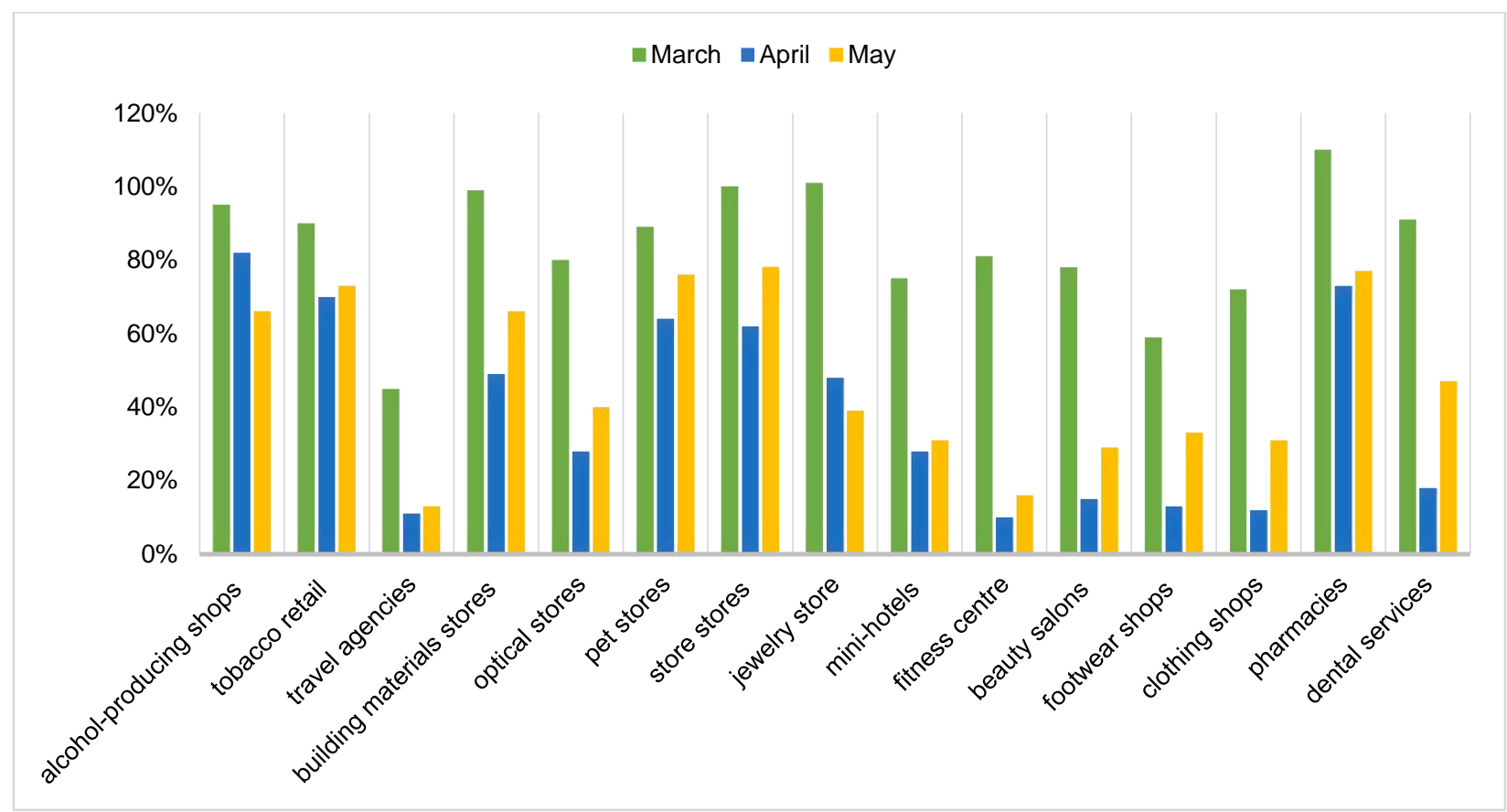

Fig. 3. Dynamics of turnover of HCB in Russia by segments - share of turnover in 2020 from 2019 (compiled by the author on the basis of data of IT-company «Evotor» Access Mode: https:///evotor.ru/)3

At the end of May, none of the small and medium-sized business segments reached the level of last year's revenues. At the same time, retail stores grew the average check. Despite the easing of restrictions imposed as early as May, none of the key segments of small and medium-sized businesses reached last year's figures. The earnings of alcohol-producing shops fell by $5 \%$ in March, by $18 \%$ in April, and by $34 \%$ in May, compared to the same figures of the previous year. The turnover of tobacco retail dropped by 10 percent in March, 30 percent in April and 27 percent in May. The turnover of pet stores and store stores declined by $36 \%$ and $38 \%$ in April, and by $24 \%$ and $22 \%$ in May, respectively. Looking at the receipts of out-of-pocket pharmacies, it can be seen that in March, at the beginning of the epidemic, turnover was $10 \%$ higher than in the previous year, due to consumer expectations, by April by $27 \%$ and in May by $23 \%$. As can be seen from the graph, the building materials stores are recovering faster than many other segments of small and medium business, due to the beginning of the dacha season.

Even under these conditions, the turnover of the industry fell by 51 percent in April and 34 percent in May. The services and retail sectors were the most affected by the restrictions: whereas in March revenue for clothing and footwear shops fell by 28 percent and 41 percent respectively, in April it had already fallen by 88 percent and 87 percent compared to 2019, and in May it had fallen by 69 percent and 67 percent. For services, the decline is as follows: turnover of fitness centers decreased by 90 percent in April, by 84 percent in May (19 percent in March), beauty salons by 85 percent in April, by 71 percent in May (22 percent in March), mini-hotels by 72 percent in April, and by 69 percent in May (25 percent in March), travel agencies in April, 89 percent, 87 percent in May (55 percent in March) and dental services - 82 percent in April, 53 percent in May (only 9 percent in March). As the statistics show, virtually all segments of small and mediumsized businesses (Golubtsova, 2019) have been affected by the spread of the pandemic and the consequent imposition of restrictive measures throughout the country. Despite the increase in turnover in May compared to April, the fall in revenue relative to 2019 is very significant (more than 40\%).

In addition to the decline in these figures, entrepreneurs have encountered other difficulties, including: inability to pay employees' salaries, problems with the payment of taxes and contributions, problems with rental payments and others. (NAFI, 2020). In this connection, since the beginning of April, the Government of 
the Russian Federation has taken a number of measures to support small and medium-sized businesses. (Petrova 2020). Most of the assistance is directed at enterprises that are included in the list of the most affected sectors, which is given in the Decisions of the Government of the Russian Federation adopted between 3 April and 26 June. These sectors include air transportation, hotel business, catering, dental practice and others. (Resolution of the Government of the English Federation of 03.04.2020 N 434 (red. of 26.04.2020), "On the approval of the list of branches of the English most affected economy by the deteriorating situation as a result of the spread of a new coronavirus infection). This list is limited and does not include many segments of entrepreneurship, which also suffer huge losses under the constraints. Among the federal-level support measures established by the Government of the Russian Federation, which have been extended to small and medium-sized enterprises from the most affected sectors, are the following:

1) Grants for salaries in April and May amounting to 12,130 roubl.per employee and interest-free wage loans;

2) Extension of the period of payment of taxes to six months, deferral of payment to one year;

3) Credit extensions of 6 months and preferential credit programme;

4) Postponement of rental payments (for State and municipal objects);

5) A moratorium on bankruptcy cases.

Measures have also been identified for small and medium-sized enterprises in all sectors, including:

a) Reduction of premium rates from 30 percent to 15 percent (above the federal SMIC);

b) Deferral of accounting and tax records;

c) A moratorium on off-site tax inspections until 30 June;

d) Prohibition of fines;

e) Change in the payment of advance income tax.

It can be seen from the list of measures that have been introduced that a lot of support is given to small and medium-sized enterprises that are included in the list of affected industries, Although the earlier data on the decline in earnings of most of the major small and medium-sized business segments show that not only the listed industries were actually affected, but almost everything was affected. Hence, the non-listed small and medium-sized enterprises find themselves in a difficult economic situation as they lack general support measures. At the same time, support measures for affected industries are also not fully effective. For example, the deferral of taxes, while alleviating the economic situation of the affected entity in the current period, does not relieve the tax burden in general, which, if deferred, will increase in the third to fourth quarter of 2020. (Korableva, 2018). That is, organizations do not have to rely on real compensation for forced demurrage, but in general most of the support measures can make life easier for the enterprise.

According to research by the NAFI Analysis Centre on the impact of the pandemic on Russian business (results of a survey of 1,500 Russian entrepreneurs at the end of March 2020) With regard to the survey on the expectations of entrepreneurs on the expected period of normalization of the situation in their industry, the following data, presented in Figure 4.

Most of the entrepreneurs surveyed rate a low-cost normalization for business - $43 \%$ believe that the situation will recover within a year. One third of the respondents expect this to happen in a few months and $14 \%$ in two to three years. In the difficult economic conditions that have arisen, which may last for a long time, accounting specialists are an important link in any small and medium-sized enterprise, whose skills and knowledge could help the organizations to survive the crisis and set them on the path to recovery in this sector of the economy. According to Rosstat, about $10 \%$ of graduates of higher education institutions in economics and accounting begin their work in small and medium-sized business. (RBK, 2020) An important aspect for the graduation of qualified persons is that, in the course of studies at institutions of higher education, a student must develop the skills with which he or she will be required in the modern labour market, and which he could apply in the process (Turishcheva, 2020). 


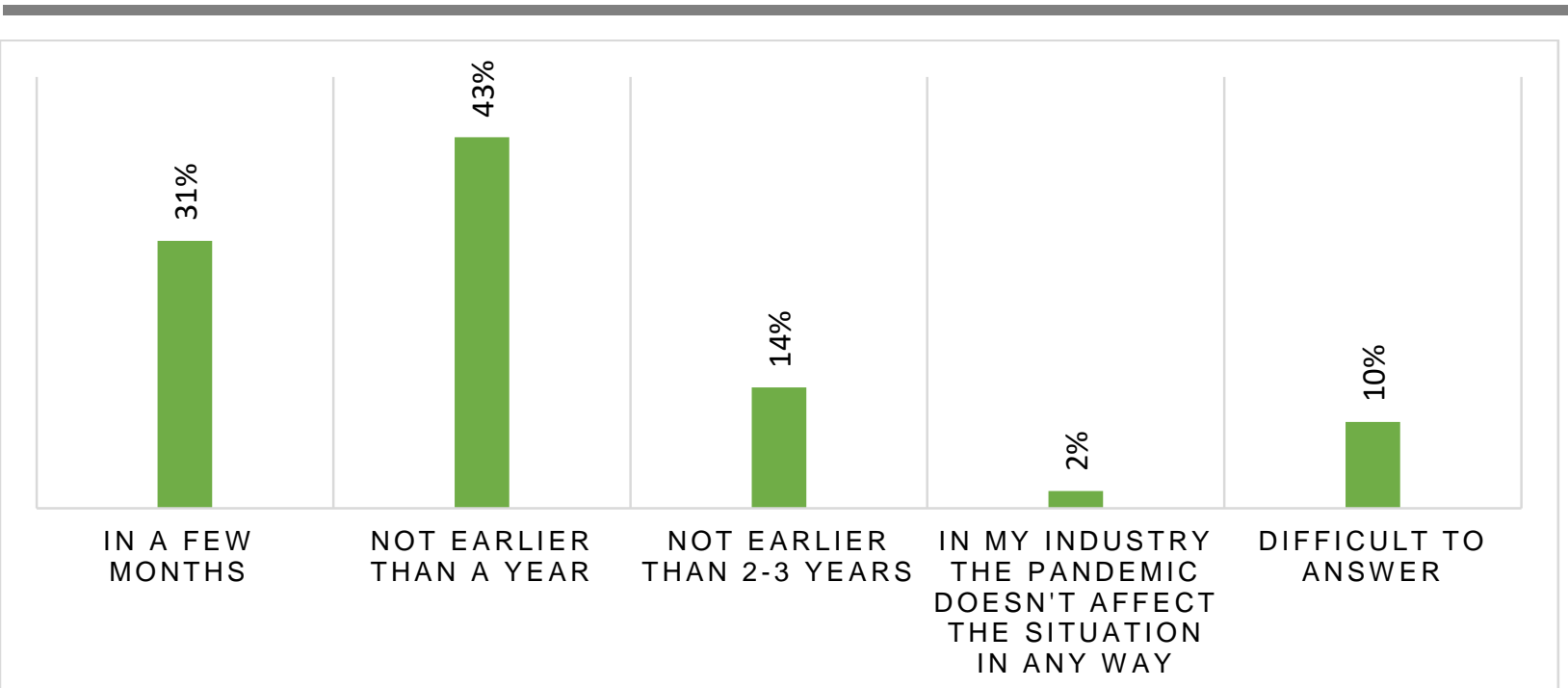

Fig. 4. Expectations of Russian entrepreneurs in small and medium-sized enterprises regarding the normalization of the situation in their sector (compiled by the author on the basis of research by the NAFI Analytical Centre Access Mode: https:///nafi.ru/ )5

At the 29 June 2020 meeting of the Government of the Russian Federation on the situation on the labour market, Anton Kotyakov, Minister of Labour and Social Protection of the Russian Federation, highlighted the mismatch of skills of part of the unemployed competences demanded by employers. (Resolution of the Government of the English Federation of 03.04.2020 N 434 (red. of 26.04.2020), "On the approval of the list of branches of the English most affected economy by the deteriorating situation as a result of the spread of a new coronavirus infection). It is worth noting that, given the complex demands of today's external environment, it is important for each higher education institution to find the right approach and trajectory that would give the graduate a theoretical and practical reserve for further work. It may be inferred from the current economic education that the knowledge acquired by students in the course of their studies is essentially theoretical, without a practical-oriented approach, which has a major impact on the quality of students' employment skills.

Considering the small and medium-sized business sector, which is currently a very important part of the Russian economy but is also highly vulnerable, as well as young professionals, We consider it an important principle to expand and deepen the study of narrowly focused economic subjects, after having studied at an institute of higher education in economics and accounting, which could provide good skills for future career applications. Important areas of study for accounting professionals for small and medium-sized enterprises may be, for example, the following: keeping records at each site in a particular organization, using programmes actually applied in companies, Reporting and interaction with governmental structures, consideration of the particularities of accounting by sector, etc. (Haykovskaya, 2020). However, theoretical approaches alone, as noted earlier, are not effective without the ability to apply knowledge in practice.

From the point of view of the practical-oriented approach in economic education, it is worth noting that the close interaction between theoretical and production activities is a condition for the preparation of graduation qualification works. Many outputs are often fully or partially a project to implement processes of economic optimization, accounting or taxation in specific small and medium-sized enterprises. On the other hand, in order to implement practical measures and skills, a system of interaction between institutions of higher education and entrepreneurial structures can be identified as an area of interaction. Such interaction can be important for all stakeholders: As a result of practical participation in the main processes in small and medium-sized enterprises, students will be able to master modern methods and tools for doing business and understanding the economy and accounting (Ternovykh, 2020). That is to say, such a system will make it possible to implement a practical-oriented approach in training and to train graduates in the skills and abilities based on solving the real needs of small and medium-sized enterprises, which are particularly acute in the current economic crisis.

\section{CONCLUSION}

The period of restrictive measures imposed in Russia as a result of the spread of the COVID-19 pandemic has become a great challenge for the Russian economy as a whole and for small and medium-sized enterprises, which have proved to be particularly vulnerable to this situation. The measures taken by the 
Government of the Russian Federation in several stages to support organizations, although extensive, are not sufficient to fully support them. The measures provided for the list of companies from the most affected industries are generally lacking for all small and medium-sized enterprises, as the study showed that virtually all sectors as a whole were actually affected, not only by the State. Tax revenues are an effective mechanism for stabilizing the economy of any country. In this regard, the promotion of entrepreneurial activity, especially of young graduates, is a necessary and necessary fiscal instrument. And its realization depends on the quality of knowledge and skills that students should be given, especially in advanced courses. It is safe to say that the emerging economic crisis gives us an understanding of the importance of the small and medium business segment of the Russian economy, which accounts for about $20 \%$ of Russia's GDP and provides millions of jobs in our country. The leadership of the country is also aware of this and speaks out. Thus, the President of Russia in a message to the Federal Assembly, indicated that by 2025 the contribution of small and medium-sized business to GDP «should approach $40 \%$ ». Of course, in the current crisis caused by the COVID-19 pandemic, these prospects can be difficult to achieve.

The current economic crisis is giving rise to the rapid application of the necessary knowledge and skills in this field that could help companies to survive and recover. However, taking into account the length of the situation and the possibility of its recurrence, we believe that it is necessary to deepen the study of narrow disciplines and to implement a practical, educational approach in the area of economics and accounting, As a result, qualified specialists will enter the small and medium-sized business sector upon completion of higher education and will be able to restore and increase the growth rate of this sector of the economy.

\section{REFERENCE LIST}

Akhmadeev, R., Morozova, T., Voronkova, O. and Sitnov, A. (2019). Targets determination model for VAT risks mitigation at B2B marketplaces. Entrepreneurship and Sustainability Issues, vol. 7(2), p. 11971216.

Avvakumova, I.V., Bykanova, O.A. and Akhmadeev, R.G. (2020) Improvement of small business owners taxation. In the Proceedings of the 7th International Conference on Education and Social Sciences (INTCESS), p. 532-537

Cowling, M., Liu, W. and Zhang, N. (2018). Did firm age, experience, and access to finance count? SME performance after the global financial crisis. Journal of Evolutionary Economics, vol. 28(1), p. 77-100

Chaykovskaya, L.A., Turishcheva, T. B. and Akhmadeev, R. G. (2020). Functional application of the internal control system in autonomous institutions. Bulletin of the National Academy of Sciences of the Republic of Kazakhstan. vol. 1 (383), p.163 - 171.

Exposito, A. and Sanchis-Llopis, J.A. (2020). The effects of innovation on the decisions of exporting and/or importing in SMEs: empirical evidence in the case of Spain. Small Bus Econ, vol. 55, p. 813-829

Facchini, F., Jaeck, L. and Bouhaddioui, C. (2020). Culture and Entrepreneurship in the United Arab Emirates. J Knowledge Economy.

Federal Law "On the Development of Small and Medium-Sized Entrepreneurship in the Russian Federation" of 24.07.2007 N 209-FEZ (red. from 08.06.2020)

Federal Law "On Education in the Russian Federation" of 29.12.2012 N 273-FZ (red. of 31.07.2020)

Golubtsova, E.V. and Zvereva, A.O. (2019) Expediency of parallel import legalization in Russian Federation. Proceedings of the 33rd International Business Information Management Association Conference, IBIMA 2019: Education Excellence and Innovation Management through Vision 2020, p. 782-787.

Jovanovic, A., Klimek, P. and Renn, O. (2020). Assessing resilience of healthcare infrastructure exposed to COVID-19: emerging risks, resilience indicators, interdependencies and international standards. Environ Syst Decis, vol. 40, p. 252-286

Juergensen, J., Guimón, J. and Narula, R. (2020). European SMEs amidst the COVID-19 crisis: assessing impact and policy responses. J. Ind. Bus. Econ., vol. 47, p. 499-510

Korableva, O. N., Kalimullina, O. V. and Mityakova, V. N. (2018). Innovation activity data processing and aggregation based on ontological modelling. Paper presented at the 2018 4th International 
Conference on Information Management, ICIM 2018, p.1-4.

Liñán, F., Paul, J. and Fayolle, A. (2020). SMEs and entrepreneurship in the era of globalization: advances and theoretical approaches. Small Business Economics, vol. 55, p. 695-703 (2020).

Morozova, T., Akhmadeev, R., Lehoux, L., Yumashev, A., Meshkova, G. and Lukiyanova, M. (2020). Crypto asset assessment models in financial reporting content typologies, Entrepreneurship and Sustainability Issues, vol. 7(3), p. 2196-2212.

Nummela, N., Vissak, T. and Francioni, B. (2020). The interplay of entrepreneurial and non-entrepreneurial internationalization: an illustrative case of an Italian SME. International Entrepreneurship and Management Journal

Orzechowski, P.E. (2020). U.S. Small Business Administration loans and U.S. state-level employment. J Econ Finan., vol. 44, p. 486-505

Petrova, G., Posadneva, E. and Morozova, T. (2019) Leading the labour market by the law of supply and demand. Sustainable Leadership for Entrepreneurs and Academics. Springer Proceedings in Business and Economics. p. 263-271.

RBK - news of the day in Russia and the world [Electronic Resource] / «Rosbusiness Consulting» news agency. - Electron. dan. - Access mode: https://wwww.rbc.ru/

Rozak, H.A. and Fachrunnisa, O. (2021) Knowledge Management Capability and Agile Leadership to Improve SMEs' Ambidexterity. In: Barolli L., Poniszewska-Maranda A., Enokido T. (eds) Complex, Intelligent and Software Intensive Systems. CISIS 2020. Advances in Intelligent Systems and Computing, vol 1194.

Ternovykh, K., Leonova, N., Malitskaya, V., Chirkova, M. and Markova, A. (2020) State and effectiveness of the Russian enterprise of horticulture production. International Transaction Journal of Engineering, Management \& Applied Sciences \$ Technologies, vol. 11 (6).

Turishcheva, T., Akhmadeev, R., Bykanova, O. and Nastasyuk, N. (2020) Methodological Support for Internal Control of Autonomous Institutions. International Journal of Applied Exercise Physiology. vol. $9(4)$, p. $53-61$ 